\title{
Bio-efficacy of Trichoderma species against Pigeonpea wilt pathogen
}

\author{
Balkishan Chaudhary*, Sanjeev Kumar and Shiva Kant Kushwaha \\ Department of Plant Pathology, College of Agriculture, Jawaharlal Nehru Krishi Vishwa Vidyalay, Jabalpur- \\ 482004 (M.P.), INDIA \\ *Corresponding author. E-mail: chaudharybalkishan480@gmail.com
}

Received: March 21, 2017; Revised received: May 30, 2017; Accepted: October 25, 2017

\begin{abstract}
Three biocontrol agent viz., Trichoderma viride, Trichoderma virens and Trichoderma harzianum were evaluated to test the antagonism against Fusarium udum under in vitro conditions. All the three biocontrol agents have the potential of parasitizing the growth of Fusarium udum in vitro. The rate of parasitism was found fastest in $T$. viride $(61.12 \%$ over growth in $96 \mathrm{hrs})$ than $T$. virens and $T$. harzianum. The volatile compounds from Trichoderma viride suppressed the mycelial growth of Fusarium udum by $43.13 \%$ and found effective when compared to Trichoderma virens and Trichoderma harzianum. Non-volatile compounds or culture filtrate from Trichoderma virens at $15 \%$ concentration shows complete mycelial inhibition of the test fungi. The antagonist $T$. virens was chosen to be the most promising bio-control agent for F. udum.
\end{abstract}

Keywords: Bio-efficacy, Fusarium udum, Pigeonpea, Trichoderma, Wilt

\section{INTRODUCTION}

Pigeonpea (Cajanus cajan (L.) Millsp.) commonly known as tur or arhar is an important pulse crop grown in northern plains, central and eastern parts of India. The total area under Pigeonpea in India was 36.3 lakh ha with a total production of 27.6 lakh tonne and 760 $\mathrm{Kg} /$ ha productivity. In Madhya Pradesh, during 20152016, Pigeonpea was cultivated in an area about 3.50 lakh hectares with production of 2.17 lakh tones and $737 \mathrm{~kg} /$ ha productivity (Shrivastava et al., 2016). Pigeonnpea provides quality food, fuel wood, and fodder. Its soil rejuvenation qualities such as release of soil-bound phosphorous, fixation of atmospheric nitrogen, recycling of soil nutrients, and addition of organic matter and other nutrients make pigeonpea an ideal crop of sustainable agriculture in the tropical and subtropical regions of India. Though several factors are known to affect pigeonpea cultivation, the most important being the diseases. Some of the important diseases are Fusarium wilt, Phytophthora blight, Cercospora leaf spot, collar rot, dry root rot, Alternaria leaf spot, powdery mildew, sterility mosaic and phyllody. Incidentally, only a few of them causes economic losses in India (Kannaiyan et al., 1984). Fusarium wilt (FW), caused by fungal pathogen Fusarium udum, is one of the major disease widely prevalent in north and central parts of the India causing yield loss ranging from 30 to $100 \%$ (Reddy et al., 1990). The yield loss due to this disease also depends upon the stage at which the plant wilt and it can approach over $50 \%$ and even up to $100 \%$ when wilt occurs at the pre pod stage (Okiror, 2002). Saxena et al. (2010) reported that
Fusarium wilt disease in pigeon pea is so devastating that it can cause production loss up to 97000 tonnes per year in India alone. The disease is soil and seed borne therefore, difficult to manage through fungicide alone. Continuous use of fungicides results in detrimental effect on environment and development of resistant strains of the pathogen, health hazards to an applicator as well as to a consumer of the treated material. Their toxic forms persist in soil and contaminate the whole environment (Hemanth et al., 2016). One of the best possible ways to reduce yield losses due to FW is to grow resistant pigeonpea varieties. Therefore, enhancement of resistance to FW in pigeonpea is a major challenge. Several studies have been conducted to understand the genetic systems that control wilt disease in pigeonpea but, conclusive evidence is yet to arrive about genetics of $\mathrm{FW}$ resistance in pigeonpea (Singh et al, 2016). Prospects of biological management of soil-borne plant pathogens using most promising biocontrol has been described (Kumar. 2013; Sabalpara et al. 2009). Successful reductions of Fusarium wilt in many crops with application of different species of Trichoderma have been found (Kumar et al., 2009; Sundaramoorthy and Balabaskar, 2013). However, it is also reported that all the isolates of Trichoderma spp. are not equally effective in management of pathogen in vitro (Biswas and Das., 1999; Ramezani, 2008). Therefore, specific isolates are needed for successful management of a particular pathogen. Therefore, the objectives of the present study were to assess the ability of three Trichoderma species in suppressing the Fusarium udum in pigeonpea under in vitro conditions. 


\section{MATERIALS AND METHODS}

Three biocontrol agent viz., Trichoderma viride, Trichoderma virens and Trichoderma harzianum were evaluated to test the antagonism against Fusarium udum the Department of Plant Pathology J.N.K.V.V. Jabalpur (M.P.) during 2015-16.

Growth of antagonist and the pathogen in monoculture and dual culture: To study the growth of antagonists and the test fungus in monoculture, 5 $\mathrm{mm}$ mycelial discs of Trichoderma viride, Trichoderma virens, Trichoderma harzianum and Fusarium udum were inoculated centrally on sterilized potato dextrose agar in Petri-dishes. Then plates were incubated in BOD incubator at $28+1{ }^{0} \mathrm{C}$. Observations on colony diameter of individual antagonist and the pathogen were recorded after $72 \mathrm{hrs}$ of incubation. For screening of the antagonists against Fusarium udum, dual culture technique developed by Morton and Straube, (1955) was adopted. Observation on colony diameter of bioagents and test fungus was recorded. Inhibition of mycelial growth of test pathogen over check was calculated by formula given by Vincent (1947). Re isolation was done by transferring $5 \mathrm{~mm}$ mycelial disc cut by cork borer from the zone where the test fungus was already overgrown by the antagonist on PDA medium to study the viability of test fungus.

Effect of volatile and non volatile compounds from antagonist(s) on the radial growth of Fusarium udum: The effect of volatile compounds from
Trichoderma viride, Trichoderma virens and Trichoderma harzianum on radial growth of Fusarium udum was followed as per the method given by (Dennis and Webster, 1971a and b). The two bottom portion of petriplates containing PDA were inoculated with a $5 \mathrm{~mm}$ disc of pathogen and antagonist, respectively and both inoculated bottom plates were placed facing each other and sealed with cellophane adhesive tape. The petriplate containing PDA without antagonist serves as control. The observations on the radial growth of the test fungus were recorded after 5 days of incubation at $28 \pm 1^{\circ} \mathrm{C}$. To study the effect of non volatile compounds, the biocontrol agents were grown in Potato dextrose broth at $27^{\circ} \mathrm{C}$ with intermittent shaking at $150 \mathrm{rpm}$. The metabolites were collected after 15 days and filtered. The sterilized filtrate was amended in PDA to make 5, 10 and $15 \%$ concentration in petriplates. The solidified agar plates in triplicates were inoculated at the centre with $5 \mathrm{~mm}$ diameter mycelial disc of pathogen and incubated at $28^{\circ} \mathrm{C}$ for 5 days. The Plates without filtrate served as control. The Colony diameter was measured and percent inhibition of radial growth was calculated using the formula given by Vincent 1947.

\section{RESULTS AND DISCUSSION}

In monoculture, Trichoderma viride showed $90 \mathrm{~mm}$ growth on PDA after $72 \mathrm{hrs}$ of incubation followed by Trichoderma virens and Trichoderma harzianum which exhibited $86.83 \mathrm{~mm}$ and $84.66 \mathrm{~mm}$ colony diameter respectively. Fusarium udum showed 36.66

\begin{tabular}{|c|c|c|c|c|}
\hline \multirow[b]{2}{*}{ Treatment } & \multirow{2}{*}{$\begin{array}{c}\text { Monoculture } \\
\begin{array}{c}\text { Colony diameter } \\
(\mathbf{m m})^{*}\end{array}\end{array}$} & \multicolumn{3}{|c|}{ Dual culture } \\
\hline & & $\begin{array}{l}\text { Colony diameter of } \\
\text { antagonist (mm)* }\end{array}$ & $\begin{array}{c}\text { Colony diameter of } \\
\text { Pathogen (mm)* }\end{array}$ & $\begin{array}{c}\text { Growth Inhibition } \\
(\%)\end{array}$ \\
\hline Trichoderma viride & 90.00 & 75.67 & 14.33 & 61.12 \\
\hline Trichoderma virens & 86.83 & 70.00 & 20.00 & 45.74 \\
\hline Trichoderma harzianum & 84.66 & 67.17 & 22.83 & 38.06 \\
\hline Fusarium udum & 36.66 & & 36.86 & - \\
\hline $\mathrm{CD}(0.05)$ & 1.723 & & 1.773 & \\
\hline
\end{tabular}

*Average of 3 replications

Table 2. Effect of volatile and non-volatile compounds from Trichoderma on radial growth of Fusarium udum after five days of incubation.

\begin{tabular}{|c|c|c|c|c|c|c|c|c|}
\hline \multirow[b]{3}{*}{ Treatment } & \multicolumn{2}{|c|}{ Volatile compounds } & \multicolumn{6}{|c|}{ Non - volatile compounds } \\
\hline & \multirow[b]{2}{*}{$\begin{array}{l}\text { Radial } \\
\text { growth of } \\
\text { mycelium } \\
\text { (mm)* }\end{array}$} & \multirow[b]{2}{*}{$\begin{array}{c}\text { Growth } \\
\text { inhibi- } \\
\text { tion } \\
(\%)\end{array}$} & \multicolumn{2}{|c|}{$5 \%$} & \multicolumn{2}{|c|}{$10 \%$} & \multicolumn{2}{|c|}{$15 \%$} \\
\hline & & & $\begin{array}{c}\text { Myceli- } \\
\text { algrowth of } \\
\text { pathogen } \\
(\mathrm{mm})^{*}\end{array}$ & $\begin{array}{l}\text { Growth } \\
\text { Inhibi- } \\
\text { tion (\%) }\end{array}$ & $\begin{array}{l}\text { Mycelial } \\
\text { growth of } \\
\text { pathogen } \\
(\mathrm{mm})^{*} \\
\end{array}$ & $\begin{array}{l}\text { Growth } \\
\text { Inhibi- } \\
\text { tion (\%) }\end{array}$ & $\begin{array}{c}\text { Mycelial } \\
\text { growth of } \\
\text { pathogen } \\
(\mathrm{mm})^{*} \\
\end{array}$ & $\begin{array}{c}\text { Growth } \\
\text { Inhibi- } \\
\text { tion } \\
(\%) \\
\end{array}$ \\
\hline $\begin{array}{l}\text { Trichoderma } \\
\text { virens }\end{array}$ & 42.17 & 31.79 & 26.17 & 57.67 & 20.50 & 66.84 & 0.0 & 100 \\
\hline $\begin{array}{l}\text { Trichoderma } \\
\text { viride }\end{array}$ & 35.16 & 43.13 & 27.83 & 54.98 & 26.86 & 56.16 & 10.83 & 82.50 \\
\hline $\begin{array}{l}\text { Trichoderma } \\
\text { harzianum }\end{array}$ & 51.00 & 17.52 & 32.00 & 48.24 & 30.17 & 51.20 & 25.16 & 59.31 \\
\hline Fusarium udum & 61.83 & -- & 61.83 & -- & 61.83 & -- & 61.83 & -- \\
\hline $\mathrm{CD}(0.05)$ & 1.851 & & 1.912 & & 1.971 & & 1.851 & \\
\hline
\end{tabular}

*Average of 3 replications 
Balkishan Chaudhary et al. / J. Appl. \& Nat. Sci. 9 (4): 2327 - 2331 (2017)

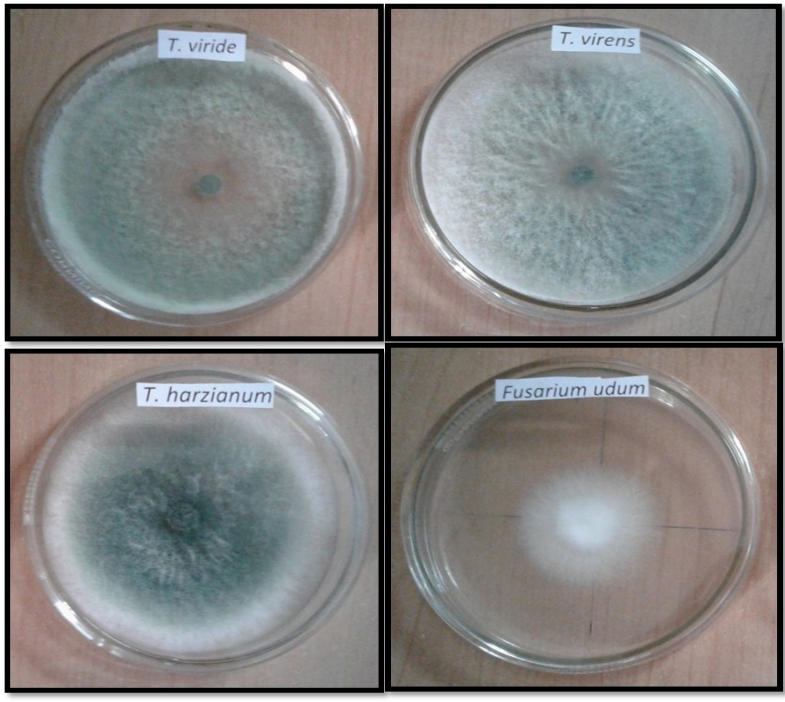

Plate 1. Growth of Trichoderma and pathogen in monoculture.

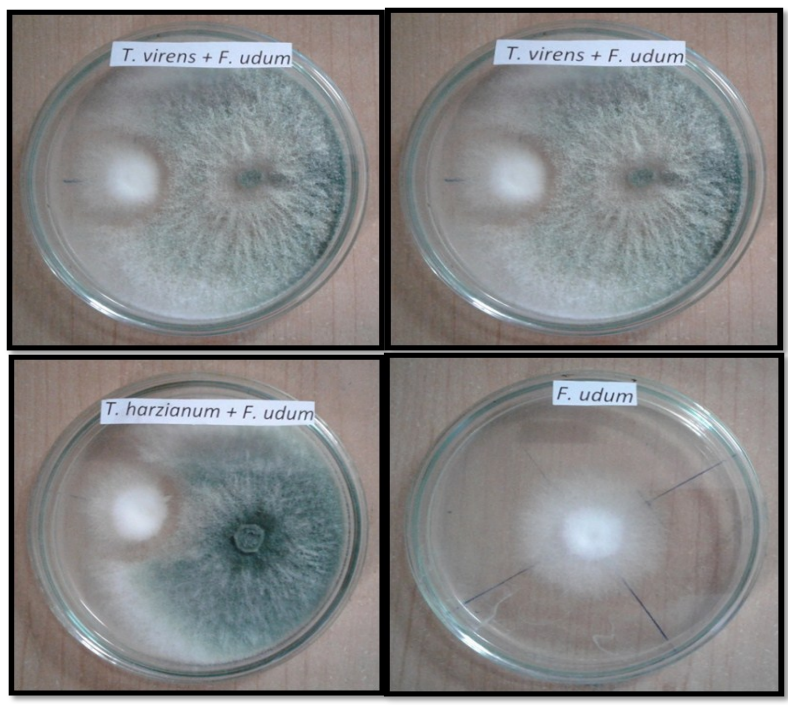

Plate 2. Growth of Trichoderma and pathogen in dual culture.

$\mathrm{mm}$ growth on PDA after 72 hrs of incubation (Table 1 and Plate 1). Singh (1991) also observed similar growth trend of bioagent. He reported that Trichoderma viride and Trichoderma virens showed $90 \mathrm{~mm}$ growth, while Trichoderma harzianum showed 76.6 $\mathrm{mm}$ growth after $72 \mathrm{hrs}$ of incubation in monoculture at $28 \pm 1{ }^{\circ} \mathrm{C}$. In dual culture, all the three antagonists parasitized the growth of Fusarium udum. The rate of inhibition was fastest in Trichoderma viride $(61.12 \%$ growth in $72 \mathrm{hrs}$ ) than Trichoderma virens $(45.75 \%$ growth in $72 \mathrm{hrs}$ ) and Trichoderma harzianum (38.06 $\%$ growth in $72 \mathrm{hrs}$ ) (Table 1 and Plate 2). Hence, Trichoderma viride proved best antagonist due to its faster and better overgrowing potential. The inhibitory effect of these bioagents against tested pathogen was probably due to competition and/or antibiosis. These results are in agreement with Chaudhary et al. (2004), Kappor et al. (2010), Kumar et al. (2014). Goudar and Kulkarni (2000) evaluated antagonistic potential of 8 antagonists under in vitro conditions, $T$. viride exhib-

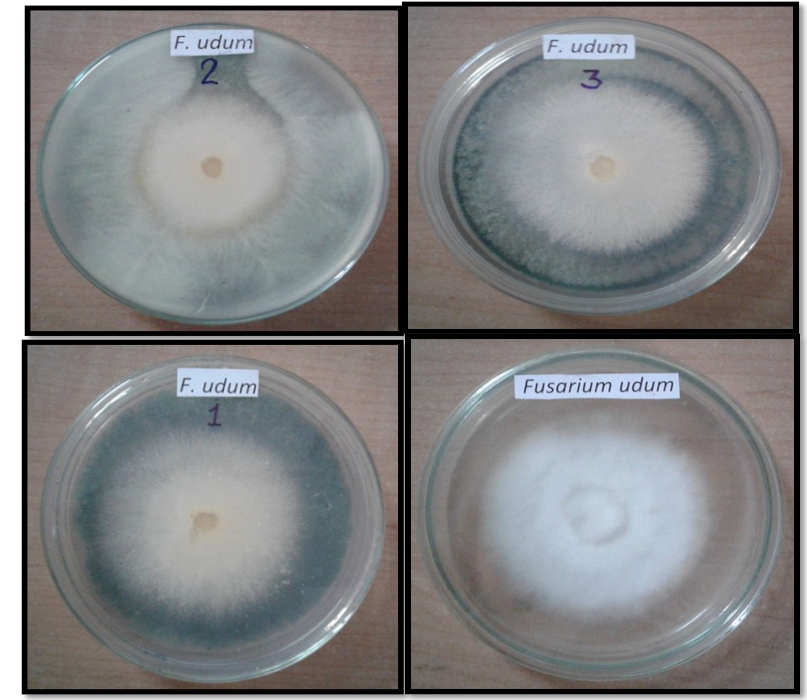

Plate 3. Effect of volatile compounds from Trichoderma on radial growth of Fusarium udum after five days and incubation.

ited the maximum inhibition, followed by $T$. harzianum . Both later overgrew and completely suppressed the test pathogen. The volatile compounds from Trichoderma viride suppressed the mycelial growth of Fusarium udum by $43.13 \%$ and found effective when compared to others (Table 2 and Plate 3 ). The nonvolatile secondary metabolites from Trichoderma species were found more effective in suppressing the mycelial growth of Fusarium udum when compared to volatile compounds. It was observed that the nonvolatile compounds from Trichoderma virens completely inhibited the radial mycelial growth of Fusarium udum at a concentration of $15 \%$ as compared to Trichoderma viride $(82.50 \%)$ and Trichoderma harzianum (59.31\%) (Table 2 and Plate 4). It was also observed that with an increase in concentration of culture filtrates of all the Trichoderma species, the radial mycelial growth of test pathogen was proportionally decreased. Chakraborty and Chatterjee (2008) studied the effect of volatile and non-volatile antibiotics of Trichoderma origin on growth inhibition of the wilt pathogen (Fusarium solani) of egg plant (Solanum melongena L.). $T$. harzianum showed maximum growth inhibition $(86.44 \%)$ of the pathogen through mycoparasitism. The non-volatiles produced by the Trichoderma species exhibited $100 \%$ growth inhibition of the pathogen under in vitro condition. Production of siderophores and fungal cell wall degrading enzymes, chitinase and $\beta$-1, 3-glucanase were found. Treatments with two most efficient Trichoderma species, $T$. harzianum and $T$. viride resulted in the decreasing population of Fusarium solani in soil thereby deterring disease incidence in field condition.Works on the effect of non-volatile compounds of Trichoderma on some more pathogens such as Botrytis fabae (Barakat et al., 2014, Fusarium moniliforme (Kumar et $a l ., 2012$ ) and other Fusarium species (Sain and Pandey, 2016) have been reported. But very few such 


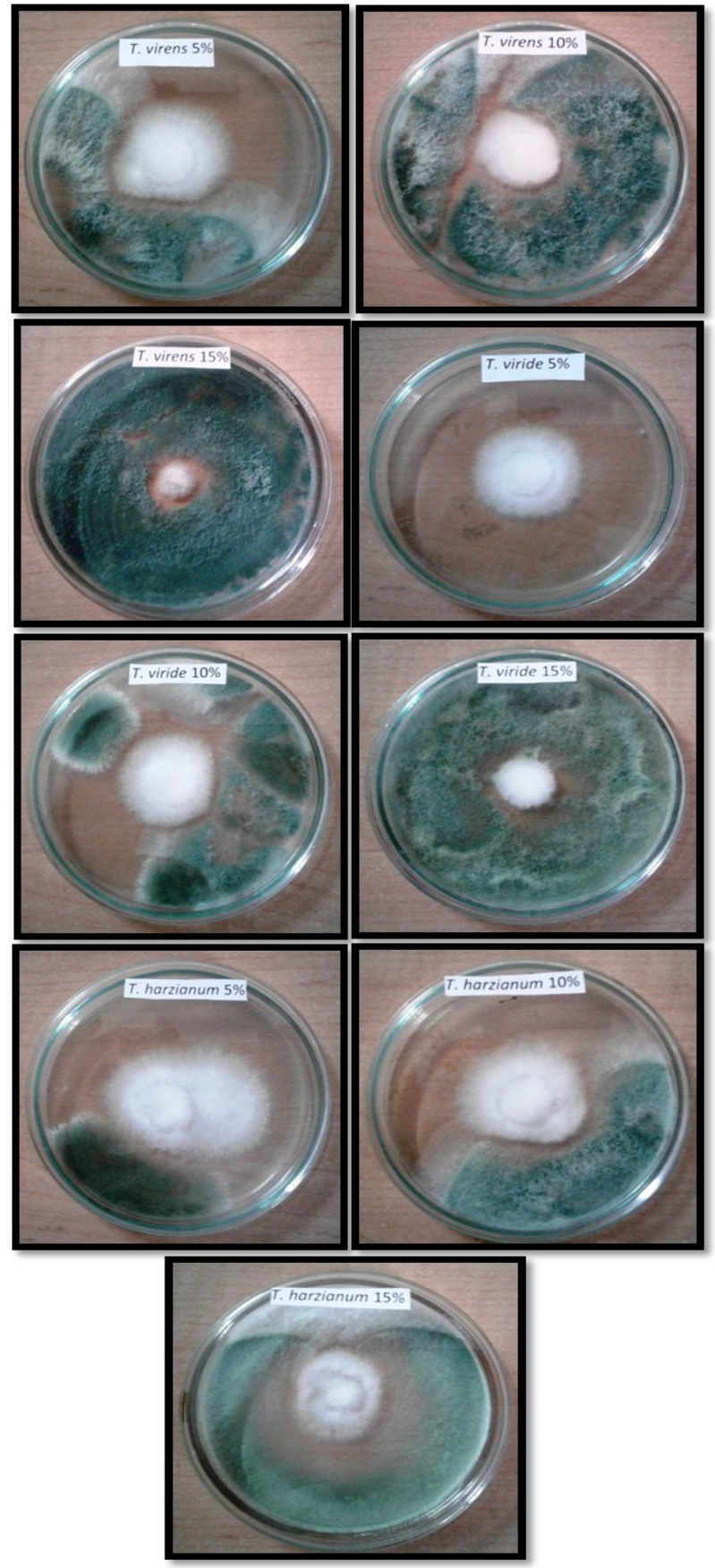

Plate 4. Effect of non-volatile compounds from Trichoderma at 5, 10 and $15 \%$ concentration on radial growth of Fusarium udum after 5 days of incubation.

works appears to have been done against $F . u d u m$, the wilt pathogen of pigeonpea. Therefore, the antagonist $T$. viride may be chosen to be the most promising biocontrol agent for $F$. udum.

\section{Conclusion}

The present evaluation thus gave clear indication that $T$ viride is strong virulent antagonist, which can be effectively used in management of pigeonpea wilt.

\section{REFERENCES}

Barakat F. M., Abada K. A., Abou-Zeid N. M., El-Gammal Y. H. E., (2014) Effect of Volatile and Non-Volatile Compounds of Trichoderma spp. on Botrytis Fabae the Causative Agent of Faba Bean Chocolate Spot, American Journal of Life Sciences. 2, (6-2), 11-18.

Biswas, K.K. and Das, N.D. (1999). Biological control of pigeon pea wilt caused by Fusarium udum with Trichoderma spp. Ann. Pl. Prot. Sci. 7: 46-50.

Chaudhary, R. G. and Prajapati, R. K. (2004). Comparative efficacy of fungal, biological agents Fusarium udum. Annals of Plant Protection Sciences. 12(1): 75-79.

Chakraborty, M.R. and Chatterjee, N.C. (2008). Control of fusarium wilt of Solanum melongena by Trichoderma spp. Biol Plant 52: 582.

Dennis, C. and Webster, J. (1971a). Antagonistic properties of species groups of Trichoderma II. Production of volatile antibiotics. Trans. Brit. Mycol. Soci. 57: 41-48.

Dennis, C. and Webster, J. (1971b). Antagonistic properties of species groups of Trichoderma I. Production of non volatile antibiotics. Trans. Brit. Mycol. Soci 57: 25-39.

Goudar, S.B \& Srikant K (2000) Bioassay of antagonists against Fusarium udum - the casual agent of pigeonpea wilt. Kar. J. of Agric. Sci. 13 (1) 64-67.

Hemanth.G., Kumar P.K.R., Niharika S.P and Samuel. K. K (2016). Fungicides effect on soil micorflora in Tekkali Mandal, Srikakulam (Dist). Int. J. Res. Dev. Pharm. L. Sci, 5 (4): 2245-2250.

Kannaiyan J., Nene Y. L., Reddy M. V., Ryan J. G., Raju T. N. (1984). Prevalence of pigeonpea diseases and associated crop losses in Asia, Africa and America. Trop. Pest Manage., 30, 62-71.

Kappor, S.,Jaishwal, A and Shukla D.N.(2010) Antagonistic effect of Trichoderma strains against F. udum causing wilt of pigeonpea. Agri. Sci. Digest., 30 (3):189-191.

Kumar, P., Misra, A.K., Dinesh, R. M., D.R \& Gupta, V.K. (2012). Biocontrol potential of Trichoderma species against mango malformation pathogens. Archies of Phytop. \& Pl. Prot. 45(10) 1237-1245.

Kumar, S. (2013). Trichoderma; A Biological Weapon for Managing Plant Diseases and Promoting Sustainability. Int. J. Agric. Sci. Vet. Med. 1: 1-16.

Kumar, S., Thakur, M. and Rani, A. (2014). Trichoderma: Mass production, formulation, quality control, delivery and its scope in commercialization in India for the management of plant diseases. Afr. J. Agric. Res. 9: 38383852 .

Kumar, S., Upadhyay, J.P. and Rani, A. (2009). Evaluation of Trichoderma species against Fusarium udum Butler causing wilt of Pigeon pea. J. Biol. Con. 23: 329-332.

Morton, D.T. and Straube, N.H. (1955). Antagonistic and stimulatory effects of microorganisms Sclerotium rolfsii . Phytopatho. 45: 419-420.

Okiror, M. A. (2002) Genetics of resistance to Fusarium udum in pigeonpea [Cajanus cajan (L.) Millsp.]. Ind J Genet Plant Breed., 62:218-220.

Ramezani, H. (2008) Biological control of root-rot of eggplant caused by Macrophomina phaseolina. Amer. Eur. J. Agric. \& Env. Sci. 4(2): 218-220.

Reddy MV, Sharma SB, Nene YL. (1990) Pigeonpea: disease management. In: Nene YL, Hall SD, Sheila VK, editors. The pigeonpea. CAB International; Wallingford, Oxon: 
pp. 303-348.

Sabalpara, A.N., Priya, J., Waghunde, R.R. and Pandya, J.P. (2009). Antagonism of Trichoderma against sugarcane wilt pathogen (Fusarium moniliformae), Amer. Eur. J. Agric. \& Env. Sci. 3: 637-638.

Sain, S.K. and Pandey, A.K. (2016). Spectrum of three isolates of Trichoderma harzianum Rifai against important fungal diseases of tomato. $6^{\text {th }}$ International Conference Plant Pathogens and People. Feb.23-27, New delhi, India.

Saxena, K.B., Kumar R.V., Dalvi, V.A., Pandey, L.B. and Gaddikeri, G. (2010). Development of cytoplasmicnuclear male sterility, its inheritance, and potential use in hybrid pigeonpea breeding. doi: 10.1093/ jhered/ esq028.

Shrivastava, V., Khare, N.K., Kinjulek, C.S. and Naberia, S.
(2016). Physiological approaches to enhance productivity in pulses under changing climate. National Conference, $30^{\text {th }}$ April, JNKVV, Jabalpur, MP.

Singh, D. (1991). Biocontrol of Sclerotinia Sclerotiorum (Lib.) de Bary T. harzianum. Trop. Pest.

Singh D., Sinha, B., Rai, V.P., Singh M.N., Singh D.K., Kumar, R., and Singh A.K. (2016). Genetics of Fusarium Wilt Resistance in Pigeonpea (Cajanus cajan) and Efficacy of Associated SSR Markers. 32(2): 95-101.

Sundaramoorthy, S. and Balabaskar, P. (2013). Biocontrol efficacy of Trichoderma spp. against wilt of tomato caused by Fusarium oxysporum f. sp. Lycopersici. J. Appl. Bio. \& Biotec. 1: 036-040.

Vincent, J.M. (1947). Distortion of fungal hyphae in presence of certain inhibitors. Nature, 154:850. 